\title{
Kontribusi Motivasi Kerja, Disiplin Kerja dan Pengembangan Karier Terhadap Kinerja Guru di SMK Negeri 1 Ranah Batahan
}

\author{
Tiwi Rahmadona ${ }^{*}$, Hasan Maksum², Eko Indrawan ${ }^{3}$, Dori Yuvenda ${ }^{4}$ iD \\ 1,2,3,4 Jurusan Pendidikan Teknologi Kejuruan, Fakultas Teknik, Universitas Negeri Padang. \\ *Corresponding author: rahtw06@gmail.com
}

\begin{abstract}
Abstrak
Kurang optimanya kinerja guru dapat dilihat dari belum kurangnya kuantitas dan kualitas kerja sesuai target yang diharapkan, serta kecepatan dan ketepatan pelaksanaan pekerjaan. Penelitian ini bertujuan untuk mengukur kontribusi motivasi kerja, disiplin kerja, dan pengembangan karier secara bersama-sama terhadap kinerja guru SMK. Penelitian ini merupakan jenis deskriptif korelasional dengan jumlah populasi dalam penelitian yakni sebanyak 67 orang guru SMK. Penarikan sampel penelitian dilakukan dengan teknik total sampling, yakni dimana seluruh jumlah populasi dijadikan sebagai sampel penelitian. Pengumpulan data dilakukan dengan menggunakan teknik wawancara, observasi dan angket. Adpaun instrument penelitian yang digunakan yakni berupa lembar kuisioner Skala Likert. Teknik analisis data diantaranya korelasi dan korelasi berganda. Hasil penelitian menunjukkan bahwa Motivasi kerja berkontribusi terhadap kinerja guru sebesar 10,18\%. Disiplin kerja berkontribusi terhadap kinerja guru sebesar 21,07\%. Pengembangan karir berkontribusi terhadap kinerja guru sebesar 18,23\%. Serta Motivasi kerja, disiplin kerja dan pengembangan karir berkontribusi bersama-sama terhadap kinerja guru sebesar 43,6\% . Berdasarkan hasil penelitian tersebut dapat disimpulkan bahwa motivasi kerja, disiplin kerja dan pengembangan karir secara bersama-sama memberikan kontribusi terhadap kinerja guru Sekolah Menengah Kejuruan.
\end{abstract}

Kata kunci: Kinerja Guru, Motivasi Kerja, Disiplin Kerja, Pengembangan Karir.

\section{Abstract}

Less optimal teacher performance can be seen from the lack of quantity and quality of work according to the expected target, as well as the speed and accuracy of the implementation of the work. This study aims to measure the contribution of work motivation, work discipline, and career development together to the performance of SMK teachers. This research is a correlational descriptive type with the total population in the study as many as 67 SMK teachers. The sampling of the research was carried out using a total sampling technique, in which the entire population was used as the research sample. Data was collected using interview, observation and questionnaire techniques. The research instrument used is in the form of a Likert Scale questionnaire sheet. Data analysis techniques include correlation and multiple correlation. The results showed that work motivation contributed to teacher performance by $10.18 \%$. Work discipline contributes to teacher performance by 21.07\%. Career development contributes to teacher performance by $18.23 \%$. As well as work motivation, work discipline and career development jointly contribute to teacher performance by 43.6\%. Based on the results of these studies, it can be concluded that work motivation, work discipline and career development together contribute to the performance of Vocational High School teachers.

Keywords: Teacher Performance, Work Motivation, Work Discipline, Career Development.

\section{INTRODUCTION}

Peningkatan profesionalisme pendidik dan tenaga kependidikan yang terkait dengan peningkatan kinerja guru adalah salah satu cara untuk mencapai tujuan pendidikan nasional (Anwar, 2020; Muspawi et al., 2020; Sonedi et al., 2018). Peningkatan mutu pendidikan pada setiap jenjang dan satuan pendidikan merupakan hal yang penting. Salah satu komponen penting dalam pendidikan yakni guru (Anggranei, 2020). Guru merupakan salah satu komponen yang menempati posisi sentral dan sangat strategi dalam sistem pendidikan (Prihartini et al., 2019). Guru menjadi faktor yang dominan dalam kaitannya dengan peningkatan kualitas pendidikan, hal ini dikarenkan guru merupakan bagian yang tidak terpisahkan dari sistem pendidikan secara keseluruhan yang terlibat langsung dalam proses belajar mengajar, dimana gurulah yang berperan langsung dalam mengajar dan mendidik (Hasibuan, 2019; Putri \& Imaniyati, 2017; Saefullah et al., 2019). Sehubungan dengan hal

\begin{tabular}{|c|c|c|}
\hline History: & & Publisher: Undiksha Press \\
\hline Received & : August 18, 2021 & Licensed: This work is licensed under \\
\hline Revised & : August 20, 2021 & a Creative Commons Attribution 3.0 License \\
\hline Accepted & October 20,2021 & (c) (†) () \\
\hline
\end{tabular}


tersebut maka kinerja guru menjadi faktor yang sangat penting dalam peningkatkan mutu pendidikan di Indonesia (Syamsul, 2017; Tanjung et al., 2021). Kinerja guru di sekolah mempunyai peran penting dalam pencapaian tujuan sekolah. Masalah kinerja akan menjadi sorotan dari berbagai pihak, kinerja pemerintah akan dirasakan oleh masyarakat dan kinerja guru akan dirasakan oleh siswa atau orang tua siswa. Guru merupakan aset utama yang berperan sebagai pilar dan ujung tombak pelaksanaan system pendidikan, karena guru merupakan pihak yang paling banyak bersentuhan langsung dengan siswa dalam proses pembelajaran (Utari \& Rasto, 2019).

Hanya saja kenyataan dilapangan menunjukkan bahwa masih terdapat beberapa guru yang memiliki kinerja rendah, seperti guru melaksanakan kegiatan belajar mengajar tidak sesuai dengan alokasi waktu yang telah ditetapkan, masih adanya sebagian guru yang menjadikan mengajar hanya sebagai kewajiban saja tanpa memikirkan kepentingan siswa dan kepentingan sekolah, kurang adanya inisiatif guru berupa kreaktifitas dalam kegiatan pembelajaran, sebagian guru masih mementingkan kepentingan pribadi diatas kepentingan sekolah, serta masih ada beberapa guru yang bolos mengajar (Fadri et al., 2021; Sulfemi, 2020; Yuniati \& Prayoga, 2019). Rendahnya kinerja guru dapat dipengaruhi oleh beberap faktor salah satunya adalah faktor motivasi kerja (Hayati et al., 2020; Kartini \& Kristiawan, 2019; Laksmi et al., 2019). Motivasi merupakan dorongan yang ada dalam diri individu, sehingga individu tersebut berkeinginan untuk melakukan kegiatan-kegiatan tertentu guna mencapai tujuan (Ardiana, 2017; Hakim \& Muhdi, 2020). Selain berasal dari dalam diri individu motivasi dapat berasal dari orang orang sekitar seperti atasan ataupun keluarga (Harefa, 2020). Dalam lingkungan sekolah pemberian motivasi kepada guru dapat dilakukan oleh kepala sekolah (Amalda \& Prasojo, 2018). Pemberian motivasi oleh kepala sekolah bertujuan agar guru dapat mencapai prestasi kerja dan meningkatkan Kinerja (Manik \& Siahaan, 2021; Muspawi et al., 2020). Tanpa motivasi, seorang guru tidak akan bisa memenuhi tugasnya sesuai standar atau bahkan melampaui standar karena apa yang menjadi motif dan motivasinya tidak terpenuhi. Selain itu tidak tercapainya tujuan suatu organisasi sekolah juga disebabkan karena sekolah tersebut memiliki motivasi kerja yang sangat rendah yang kemudian berdampak pada lemahnya kinerja para pegawainya.

Selain dipengaruhi oleh motivasi kerja, kualitas kinerja guru juga dapat dipengaruhi oleh faktor disiplin kerja. Prilaku displin merupakan suatu bentuk kesadaran dan kesediaan seseorang mentaati semua peraturan perusahaan dan norma-norma yang berlaku (Dewi \& Khotimah, 2020; Sya'roni et al., 2018). Disiplin kerja seorang guru dapat dilihat dari sikap kepatuhan guru terhadap peraturan yang berlaku di sekolah (Utari \& Rasto, 2019). Disiplin kerja sangat memberikan pengaruh terhadap kinerja guru karena kedisiplinan mampu menjadi tenaga pendorong kemauan dan keinginan untuk bekerja menurut ukuran-ukuran dan batasanbatasan yang ditetapkan sehingga jelas bahwa disiplin sudah semestinya dimiliki oleh seorang guru agar menunjang suksesnya proses pembelajaran (Juniarti et al., 2020; Pala'langan, 2020; Suciningrum et al., 2021; Wijania, 2017). Tanpa adanya sikap disiplin kerja tujuan-tujuan pendidikan tidak akan dapat tercapai dengan maksimal. Seorang guru yang memiliki tingkat kedisiplinan yang tinggi akan tetap bekerja dengan baik walaupun tanpa diawasi oleh atasan, tidak akan mencuri waktu kerja untuk melakukan hal-hal lain yang tidak ada kaitannya dengan pekerjaan, serta akan mentaati peraturan yang ada dalam lingkungan kerja dengan kesadaran yang tinggi tanpa ada rasa paksaan (Kristianti et al., 2021; Syaleh, 2018).Peningkatan motivasi serta disiplin kerja guru dapat dilakukan dengan memberikan kegiatan pengembangan karir. Pengembangan karir pada dasarnya sangatlah dibutuhkan oleh guru, hal ini dikarenakan pengembangan karir berorientasi pada tantangan masa yang akan datang dalam menghadapi pesaing serta perkembangan teknologi (Wardhani \& Wijaya, 2020). Pengembangan karir memiliki eksistensi dimasa depan yang tergantung pada kualitas dan kinerja sumber daya manusianya, karenanya organisasi harus melakukan pembinaan karir pada pekerja yang 
dilaksanakan secara berencana dan berkelanjutan (Rusby \& Hamzah, 2017). Pembinaan dan pengembangan karier guru terdiri dari tiga ranah, yaitu penugasan, kenikan pangkat, dan promosi (Lutfiyanto et al., 2020). Sebagai bagian dari pengembangan karier, kenaikan pangkat merupakan hak guru. Dalam kerangka pembinaan dan pengembangan, kenaikan pangkat ini termasuk ranah peningkatan karier. Kenaikan pangkat ini dilakukan melalui dua jalur. Pertama, kenaikan pangkat dengan sistem pengumpulan angka kredit. Kedua, kenaikan pangkat karena prestasi kerja atau dedikasi yang luar biasa.

Beberapa penelitian yang telah dilakukan sebelumnya menyebutkan bahwa pengembangan karir melalui kepuasan kerja secara tidak langsung memberikan positif dan signifikan terhadap kinerja guru (Rusby \& Hamzah, 2017). Penelitian lainnya menyebutkan bahwa terdapat hubungan yang signifikan antara motivasi kerja dengan prestasi kerja guru, hal ini menunjukkan bahwa semakin tinggi motivasi kerja maka akan semakin baik pula prestasi kerja guru, begitu pula berlaku sebaliknya (Harefa, 2020). Selain dipengaruhi oleh pengembangan karir dan motivasi kerja, kinerja guru juga dipengaruhi oleh disiplin kerja (Utari \& Rasto, 2019). Berdasarkan beberapa penelitian tersebut dapat dikatakan bahwa motivasi kerja, pengembangan karir, dan disiplin kerja mampu mempengaruhi kinerja seorang guru. Hanya saja pada penelitian sebelumnya belum terdapat kajian yang membahas secara bersamasama hubungan anatara kontribusi motivasi kerja, disiplin kerja dan pengembangan karier terhadap kinerja guru. Sehingga penelitian ini difokuskan pada kajian tersebut dengan tujuan untuk mengukur kontribusi motivasi kerja, disiplin kerja, dan pengembangan karier secara bersama-sama terhadap kinerja guru SMK.

\section{MATERIALS AND METHODS}

Penelitian ini merupakan jenis penelitian korelasi (ex-post-facto) yang dirancang untuk menentukan tingkat hubungan variabel-variabel yang berbeda. Populasi dalam penelitian ini yakni guru SMK Negeri 1 Ranah Batahan yang berjumlah 67 orang dengan teknik pengambilan sampelnya secara total sampling. Pada teknik total sampling seluruh populasi digunakan sebagai sampel penelitian. Pengumpulan data dalam penelitian dilakukan dengan menggunakan teknik wawancara, observasi, dan penyebaran angket kepada sampel penelitian. Adapun instrument penelitian yang digunakan yakni berupa instrument angket dengan menggunakan skala likert. Data hasil penelitian kemudian dianalisis dengan menggunakan teknik analisis data deskripsi yakni berupa skor mean (nilai rerata), median, modus, dan standar deviasi. Pengujian persyaratan analisis dilakukan dengan uji normalitas, uji homogenitas, dan uji linearitas. Sedangkan pengujian hipotesis dilakukan menggunakan analisis korelasi sederhana dan regresi ganda.

\section{RESULTS AND DISCUSSION Results}

Data yang dipaparkan dalam penelitian ini adalah data hasil motivasi kerja, disiplin kerja, pengembangan karir sebagai variabel bebas (X) dan kinerja guru sebagai variabel terikat (Y). Berdasarkan distribusi frekuensinya, kinerja guru dapat diklasifikasikan ke dalam beberapa kategori seperti yang disajikan pada Tabel 1. Tabel 1 menunjukkan bahwa variabel kinerja guru pada umumnya berada pada kategori sedang dengan jumlah persentase sebanyak $52,24 \%$, sedangkan pada kategori tidak baik hanya sebesar 2,99\%. Hasil tersebut menunjukkan bahwa kinerja guru berada pada ketegori sedang untuk SMKN 1 Ranah Batahan. Derajat pencapaian kinerja guru berada pada kategori cukup. Hal ini berarti masih memperoleh kinerja guru masih perlu ditingkatkan agar mutu pendidikan dapat ditingkatkan lebih baik. Analisis selanjutnya dilakukan untuk mengetahui Distribusi frekuensinya motivasi kerja guru. Adapun pengklasifikasian dat amotivasi kerja guru dapat dilihat pada Tabel 2. 
Tabel 1. Klasifikasi Data Kinerja Guru.

\begin{tabular}{lccc}
\hline Kategori & Rentang & Jumlah Responden & $\begin{array}{c}\text { Persentase } \\
(\mathbf{\%})\end{array}$ \\
\hline Sangat Baik & $\geq 148$ & 6 & 8.96 \\
Baik & $140-147$ & 10 & 14.93 \\
Sedang & $133-139$ & 35 & 52.24 \\
Kurang baik & $126-132$ & 14 & 20.90 \\
Tidak baik & $\leq 125$ & 2 & 2.99 \\
Jumlah & & & $\mathbf{1 0 0}$ \\
\hline
\end{tabular}

Tabel 2. Klasifikasi Data Motivasi Kerja.

\begin{tabular}{lccc}
\hline Kategori & Rentang & Jumlah Responden & $\begin{array}{c}\text { Persentase } \\
(\boldsymbol{\%})\end{array}$ \\
\hline Sangat Baik & $\geq 119$ & 5 & 7.46 \\
Baik & $114-118$ & 12 & 17.91 \\
Sedang & $109-113$ & 29 & 43.28 \\
Kurang baik & $104-108$ & 19 & 28.36 \\
Tidak baik & $\leq 103$ & 2 & 2.99 \\
Jumlah & & & $\mathbf{1 0 0}$ \\
\hline
\end{tabular}

Berdasarkan Tabel 2 dapat diketahui bahwa data kategori pada variabel motivasi kerja guru berada pada kategori sedang sebanyak $43,28 \%$, sedangkan pada kategori tidak baik hanya $2,99 \%$. Hasil tersebut menunjukkan bahwa motivasi kerja guru dalam melakukan tugasnya berada pada ketegori sedang untuk SMKN 1 Ranah Batahan. Derajat pencapaian motivasi kerja guru di SMK Negeri 1 Ranah Batahan berada pada kategori cukup. Hal ini berarti guru di SMK Negeri 1 Ranah Batahan memiliki motivasi kerja yang masih cukup untuk melaksanakan tugasnya. Analisis selanjutnya dilakukan untuk mengetahui distrubusi frekuensi variabel disiplin kerja, yang kemudian diklasifikasikan seperti pada Tabel 3. Hasil penelitian menunjukkan bahwa variabel disiplin kerja guru berada pada kategori sedang dengan jumlah persentase sebanyak 55,22\%, sedangkan pada kategori tidak baik hanya $7,46 \%$. Jadi berdasarkan hasil temuan dapat disimpulkan disiplin kerja guru dalam melakukan tugasnya berada pada ketegori sedang untuk SMKN 1 Ranah Batahan. Derajat pencapian disiplin kerja guru di SMK Negeri 1 Ranah Batahan berada pada kategori cukup. Hal ini berarti disiplin kerja di SMK Negeri 1 Ranah Batahan masih kurang maksimal dalam melakanakan kinejanya. Analisis selanjutnya dilakukan untuk mengetahui distribusi frekuensi pengembangan karir guru. Adapun klasifikasi data pengembangan karir dapat dilihat pada Tabel 4.

Tabel 3. Klasifikasi Data Disiplin Kerja

\begin{tabular}{llll}
\hline Kategori & Rentang & Jumlah Responden & $\begin{array}{l}\text { Persentase } \\
(\boldsymbol{\%})\end{array}$ \\
\hline Sangat Baik & $\geq 84$ & 5 & 7.46 \\
Baik & $79-83$ & 12 & 17.91 \\
Sedang & $73-78$ & 37 & 55.22 \\
Kurang baik & $68-72$ & 8 & 11.94 \\
Tidak baik & $\leq 67$ & 5 & 7.46 \\
Jumlah & & & $\mathbf{1 0 0}$ \\
\hline
\end{tabular}


Tabel 4. Klasifikasi Data Pengembangan Karir

\begin{tabular}{lccc}
\hline Kategori & Rentang & $\begin{array}{c}\text { Jumlah } \\
\text { Responden }\end{array}$ & $\begin{array}{c}\text { Persentase } \\
(\boldsymbol{\%})\end{array}$ \\
\hline Sangat Baik & $\geq 108$ & 8 & 11.94 \\
Baik & $104-107$ & 16 & 23.88 \\
Sedang & $99-103$ & 29 & 43.28 \\
Kurang baik & $95-98$ & 10 & 14.93 \\
Tidak baik & $\leq 94$ & 4 & 5.97 \\
Jumlah & & & $\mathbf{1 0 0}$ \\
\hline
\end{tabular}

Berdasarkan Tabel 4 dapat diketahui bahwa variabel pengembangan karir guru berada pada kategori sedang dengan jumlah persentase sebesar 43,28\%, sedangkan pada kategori tidak baik hanya 5,97\%. Berdasarkan hasil temuan tersebut dapat disimpulkan bahwa pengembangan karir guru dalam melakukan tugasnya berada pada ketegori sedang untuk SMKN 1 Ranah Batahan. Derajat pencapian pengembangan karir guru di SMK Negeri 1 Ranah Batahan berada pada kategori cukup. Hal ini berarti pengembangan karir guru di SMK Negeri 1 Ranah Batahan masih perlu ditingkatkan agar mendorong semangat guru dalam melakanakan kinejanya. Sebelum melakukan analisis uji hipotesis, terlebih dahulu dilakukan uji asumsi diantara, uji normalitas, uji homogenitas, dan uji linearitas. Uji normalitas yang digunakan dalam penelitian ini adalah suatu uji untuk melihat residual sebaran data yang dimiliki berasal dari sebaran normal atau tidaknya yaitu menggunakan teknik Komogorov Smirnov dengan menetapkan taraf signifikan 5\% atau $\alpha=0,05$. Data dapat dikatakan berdistribusi normal jika taraf signifikan (Asymp.Sig) > 0,05 maka data berdistribusi normal, adapun hasil pemeriksaan dapat dilihat pada Tabel 5. Hasil perhitungan normalitas variabel motivasi kerja $\left(\mathrm{X}_{1}\right)$, disiplin kerja $\left(\mathrm{X}_{2}\right)$ dan pengembangan karir $\left(\mathrm{X}_{3}\right)$ terhadap kinerja guru belajar $(\mathrm{Y})$ diperoleh nilai Asymp Sig lebih besar dari 0,05. Jadi data dinyatakan berdistribusi normal. Uji homogenitas adalah uji yang dilakukan untuk melihat apakah data yang diperoleh berasal dari sampel yang homogen. Uji homogenitas varians populasi dilakukan dengan Test Homogenity of Variance. Hasil analsis data diajikan pada Tabel 6.

Tabel 5. Hasil Uji Normalitas

\begin{tabular}{lcccc}
\hline Variabel & KS & Asymp Sig & Pengujian & Ket \\
\hline Motivasi kerja $\left(\mathrm{X}_{1}\right)$ & 1,274 & 0.078 & 0,05 & Normal \\
Disiplin kerja $\left(\mathrm{X}_{2}\right)$ & 1,154 & 0,139 & 0,05 & Normal \\
Pengembangan Karir $\left(\mathrm{X}_{3}\right)$ & 0.782 & 0.574 & 0,05 & Normal \\
Kinerja guru $(\mathrm{Y})$ & 0.690 & 0.728 & 0,05 & Normal \\
\hline
\end{tabular}

Tabel 6. Uji Homoenitas

\begin{tabular}{lccc}
\hline Variabel & $\boldsymbol{I G}$ & Pengujian & Ket \\
\hline Motivasi kerja $\left(\mathrm{X}_{1}\right)$ & 0,375 & 0,05 & Homogen \\
Disiplin kerja $\left(\mathrm{X}_{2}\right)$ & 0,107 & 0,05 & Homogen \\
Pengembangan Karir $\left(\mathrm{X}_{3}\right)$ & 0,052 & 0,05 & Homogen \\
\hline
\end{tabular}

Hasil menunjukkan bahwa nilai signifikansi masing-masing lebih besar dari 0,05 maka dapat disimpulkan bahwa sebaran data sudah homogen karena nilai sig $>0.05$. Uji linearitas dilakukan untuk mengetahui apakah dua variabel mempunyai hubungan yang linear atau tidak signifikan dan juga sebagai persyaratan dalam analisis korelasi atau regresi, apabila taraf signifikan antara dua variabel kurang dari 0,05 maka dikatakan mempunyai hubungan yang 
linear. Hasil pengujian linearitas dapat dilihat pada Tabel 7. Hasil analisis menunjukkan nilai signifikan pada linearitas $\mathrm{X}_{3}$ terhadap $\mathrm{Y}$ sebesar 0,172 , karena signifikansinya kurang dari 0,05 maka dapat disimpulkan bahwa antara variabel pengembangan karir $\left(\mathrm{X}_{3}\right)$ terhadap kinerja guru (Y) terdapat hubungan yang linear.

Tabel 7. Hasil Linearitas

\begin{tabular}{lccc}
\hline & $\begin{array}{c}\text { Deviation From } \\
\text { Linearity }\end{array}$ & Taraf signifikan & Kesimpulan \\
\hline $\begin{array}{l}\text { Motivasi kerja terhadap kinerja } \\
\text { (X1Y) }\end{array}$ & 0,0419 & 0,05 & Linear \\
$\begin{array}{l}\text { Disiplin terhadap kinerja (X2Y) } \\
\begin{array}{l}\text { Pengembangan karir terhadap } \\
\text { kinerja (X3Y). }\end{array}\end{array}$ & 0,167 & 0,05 & Linear \\
\hline
\end{tabular}

Pengujian hipotesis dapat dilakukan apabila telah memenuhi ketiga uji asumsi telah dilakukan. Uji hipotesis dilakukan dengan menggunakan teknik analisis regresi korelasi sederhana untuk menguji hipotesis 1 dan 2 dan analisis regresi korelasi berganda untuk menguji hipotesis 3. Adapun hipotesis yang diuji adalah hipotesis nol $\left(\mathrm{H}_{0}\right)$. Hipotesis dalam korelasi tersebut diuji dengan menggunakan uji $\mathrm{r}$ dengan kriteria pengujian, terima Ho jika $\mathrm{r}_{\text {hitung }}<\mathrm{r}_{\text {tabel }}$ dan tolak $\mathrm{H}_{0}$ jika $\mathrm{r}_{\text {reg }}>\mathrm{r}_{\text {tabel }}$, $\mathrm{r}_{\text {tabel }}$ ditentukan dari tabel distirbusi $\mathrm{r}$ untuk $=0,05$. Berdasarkan hasil analisis untuk hasil pengujian untuk pengujian pertama diperoleh $\mathrm{r}_{\text {hitung }}=0,319$ dengan signifikansi sebesar 0,009 sehingga Ho ditolak maka dapat dirangkum bahwa motivasi kerja berhubungan signifikan dengan kinerja guru dengan kontribusi sebesar 10,18\%. Hasil analisis untuk pengujian hipotesis kedua diperoleh $\mathbf{r}_{\text {hitung }}=0,4599$ dengan signifikansi sebesar 0,000, sehingga Ho ditolak maka dapat dirangkum bahwa disiplin kerja berhubungan signifikan dengan kinerja guru dengan kontribusi sebesar 21,07\%. Hasil analisis untuk pengujian hipotesis ketiga diperoleh $\mathrm{r}_{\text {hitung }}=0,428$ dengan signifikansi sebesar 0,000 sehingga Ho ditolak, maka dirangkum bahwa pengembangan karir berhubungan signfikan dengan kinerja guru dengan kontribusi sebesar 18,32\%. Hasil analisis untuk pengujian hipotesis keempat diperoleh $\mathrm{r}_{\text {hitung }}=0,620$ dengan signifikansi sebesar 0,000 sehingga Ho ditolak, maka dirangkum bahwa motivasi kerja, disiplin kerja dan pengembangan karir berhubungan positif dan signifikan dengan kinerja guru dengan kontribusi sebesar 38,44\%.

\section{Discussion}

Hasil penelitian yang telah dilakukan menunjukkan bahwa kinerja guru dapat dipengaruhi oleh berbagai faktor. Hal ini dikarenakan kinerja guru merupakan merupakan kualitas kerja guru dan kualitas yang ingin dicapai dalam pendidikan oleh guru sesuai dengan tanggung jawab yang dibawanya selaku tenaga pendidik atau pengajar (Pala'langan, 2020; Suciningrum et al., 2021; Wijania, 2017). Terdapat berbagai macam faktor yang dapat mempengaruhi kinerja guru. Faktor pertama yakni motivasi kerja, motivasi kerja merupakan merupakan daya dorong bagi guru dalam melaksanakan pekerjaan yang mengarah kepada sasaran sebagai kepuasan, yang kemudian menimbulkan perasaan senang atas hasil pekerjaan (Kristianti et al., 2021; Syaleh, 2018). Motivasi menjadi langkah awal seorang guru untuk melakukan tindakan sebagai suatu dorongan yang ditunjukkan untuk memenuhi tujuan tertentu (Manik \& Siahaan, 2021). Guru yang memiliki motivasi kerja tinggi tentunya akan memiliki kemauan untuk melaksanakan proses pembelajaran dengan bersungguh-sungguh (Ardiana, 2017; Hakim \& Muhdi, 2020; Kartini \& Kristiawan, 2019). Selain berasal dari dalam diri dorongan untuk melakukan proses pembelajaran juga dapat berasal dari lingkungan sekitar 
seperti dari atasan maupun keluarga. Dorongan yang diberikan kepada guru dapat berupa dorongan moral seperti memberikan semangat dan penghargaan kepada guru yang berprestasi.

Selain dipengaruhi oleh motivasi kerja, kinerja guru juga dipengaruhi oleh disiplin kerja. Semakin baik disiplin kerja seseorang, maka semakin tinggi hasil prestasi kerja (kinerja) yang akan dicapai (Syaleh, 2018). Disiplin kerja merupakan suatu bentuk prilaku yang menunjukkan bagaimana seseorang bertanggung terhadap tugas-tugas yang diberikan kepadanya (Dewi \& Khotimah, 2020; Juniarti et al., 2020). Disiplin kerja yang baik mencerminkan besarnya rasa tanggung jawab seseorang terhadap tugas-tugas yang diberikan kepadanya (Purwoko, 2018). Hal ini mendorong gairah kerja, semangat kerja dan terwujudnya tujuan. Melalui peningkatan disiplin kerja guru akan mampu mendayagunakan sumber dayanya secara optimal, dan mendudukan sekolah pada posisi persaingan pasar yang lebih kuat dibandingkan dengan sekolah asing (Rochimah et al., 2018). Penanaman sikap disiplin sejak dini akan dapat menumbuhkan rasa tanggung jawab dalam melaksanakan tugas yang diembannya dan dapat mewujudkan suasana pembelajaran yang baik (Harefa, 2020). Guru yang disiplin adalah guru yang memiliki sikap professional, sehingga dapat dikatakan bahwa guru yang profesional adalah mereka yang memiliki kemampuan profesional dengan berbagai kapasitasnya sebagai pendidik (Amalda \& Prasojo, 2018). Guru profesional memiliki pengalaman mengajar, kapasitas intelektual, moral, keimanan, ketakwaan, disiplin, tanggung jawab, wawasan kependidikan yang luas, kemampuan manajerial, terampil, kreatif, memiliki keterbukaan profesional dalam emahami potensi, karakteristik dan masalah perkembangan peserta didik, mampu engembangkan rencana studi dan karir peserta didik serta memiliki kemampuan meneliti dan mengembangkan kurikulum (Messi et al., 2018).

Adapun faktor lain yang mempengaruhi kinerja guru adalah pengembangan karir. Pengembangan karir merupakan kenaikan pada posisi karyawan di perusahaan dalam jalur profesi yang sudah ditentukan untuk meningkatkan kinerjanya (Lutfiyanto et al., 2020). Dengan adanya standar hidup yang selalu berubah-ubah, karyawan selalu merasa kurang puas dengan jabatan yang dimiliki dan selalu ingin mendapatkan kenaikan jabatan yang tentu saja akan berpengaruh pada gaji/upah yang diperoleh (Mukti, 2016). Efisiensi maupun efektivitas organisasi sangat bergantung pada baik buruknya pengembangan sumber daya manusia/anggota organisasi itu sendiri. Dengan demikian jelaslah bahwa program pengembangan karir karyawan dalam organisasi sangat penting artinya dalam rangka memajukan organisasi yang bersangkutan, terlebih apabila pengetahuan dan teknologi makin berkembang dengan pesat.

Hasil yang diperoleh pada penelitian ini sejalan dengan hasil penelitian terdahulu yang juga mengungkapkan bahwa pengembangan karir melalui kepuasan kerja secara tidak langsung memberikan positif dan signifikan terhadap kinerja guru (Rusby \& Hamzah, 2017). Penelitian lainnya menyebutkan bahwa terdapat hubungan yang signifikan antara motivasi kerja dengan prestasi kerja guru, hal ini menunjukkan bahwa semakin tinggi motivasi kerja maka akan semakin baik pula prestasi kerja guru, begitu pula berlaku sebaliknya (Harefa, 2020). Selain dipengaruhi oleh pengembangan karir dan motivasi kerja, kinerja guru juga dipengaruhi oleh disiplin kerja (Utari \& Rasto, 2019). Sehingga berdasarkan hasil penelitian tersebut dapat diketahui bahwa motivasi kerja, disiplin kerja, serta pengembangan karir merupakan faktorfaktor yang menjadi penentu kualitas kinerja seseorang.

\section{CONCLUSION}

Simpulan yang dapat ditarik dari hasil penelitian ini yakni motivasi kerja berkontribusi terhadap kinerja guru, disiplin kerja berkontribusi terhadap kinerja guru, serta pengembangan karir berkontribusi terhadap kinerja guru. Berdasarkan ketiga hal tersebut dapat disimpulkan bahwa Motivasi kerja, disiplin kerja dan pengembangan karir berkontribusi bersama-sama 
terhadap kinerja. Kinerja guru dapat ditingkatkan jika guru, pimpinan dan pemerintah berupaya meningkatkan motiwasi kerja, disiplin kerja dan pengembangan karir dengan baik. Dengan demikain mutu pendidikan dapat ditingkatkan.

\section{REFERENCES}

Amalda, N., \& Prasojo, L. D. (2018). Pengaruh motivasi kerja guru, disiplin kerja guru, dan kedisiplinan siswa terhadap prestasi belajar siswa. Jurnal Akuntabilitas Manajemen Pendidikan, 6(1), 11. https://doi.org/10.21831/amp.v6i1.7515.

Anggranei, F. N. (2020). Realitas Kompetensi Guru Pasca Sertifikasi. Scientific Journal Of Reflection: Economic, Accounting, Management and Business, 3(4), 331-340. https://doi.org/10.37481/sjr.v3i4.229.

Anwar, A. S. (2020). Pengembangan Sikap Profesionalisme Guru Melalui Kinerja Guru Pada Satuan Pendidikan MTS Negeri 1 Serang. Andragogi: Jurnal Pendidikan Islam Dan Manajemen Pendidikan Islam, 2(1), 147-173. https://doi.org/10.36671/andragogi.v2i1.79.

Ardiana, T. E. (2017). Pengaruh Motivasi Kerja Guru Terhadap Kinerja Guru Akuntansi SMK Di Kota Madiun. Jurnal Akuntansi Dan Pajak, 17(02). https://doi.org/10.29040/jap.v17i02.11.

Dewi, R., \& Khotimah, S. H. (2020). Pengaruh Profesionalisme Dan Disiplin Kerja Guru Terhadap Peningkatan Mutu Pendidikan Di Sekolah Dasar. ELEMENTARY: Islamic Teacher Journal, 8(2), 279. https://doi.org/10.21043/elementary.v8i2.7839.

Fadri, F., Saam, Z., \& Suarman, S. (2021). Hubungan Antara Motivasi Berprestasi Dan Kepuasan Kerja Dengan Kinerja Guru Pada Smp Di Kecamatan Bangkinang Kota Kabupaten Kampar. Jurnal Jumped (Jurnal Manajemen Pendidikan), 9(1), 1. https://doi.org/10.31258/jmp.9.1.p.1-13.

Hakim, A. R., \& Muhdi, M. (2020). Motivasi Kerja Dan Kompensasi Terhadap Kepuasan Kerja Guru SMK Swasta Di Wilayah Timur Kabupaten Pemalang. Jurnal Pendidikan Ilmu Sosial, 29(2), 105-115. https://doi.org/10.23917/jpis.v29i2.9354.

Harefa, D. (2020). Pengaruh Antara Motivasi Kerja Guru IPA dan Displin Dengan Prestasi Kerja. Aksara: Jurnal Ilmu Pendidikan Nonformal, 6(3), 225. https://doi.org/10.37905/aksara.6.3.225-240.2020.

Hasibuan, A. A. (2019). Analisis Faktor-Faktor Peningkatan Kinerja Guru Dalam Upaya Pencapaian Kualitas Proses Pembelajaran Di Sekolah. Al Amin: Jurnal Kajian Ilmu Dan Budaya Islam, 2(02), 149-159. https://doi.org/10.36670/alamin.v2i02.23.

Hayati, R., Arafat, Y., \& Sari, A. P. (2020). Pengaruh Komitmen Organisasi Dan Motivasi Kerja Terhadap Kinerja Guru. JMKSP (Jurnal Manajemen, Kepemimpinan, Dan Supervisi Pendidikan), 5(2), 100. https://doi.org/10.31851/jmksp.v5i2.3753.

Juniarti, E., Ahyani, N., \& Ardiansyah, A. (2020). Pengaruh Kepemimpinan Kepala Sekolah dan Disiplin Guru terhadap Kinerja Guru. Journal of Education Research, 1(3), 193199. https://doi.org/10.37985/joe.v1i3.21.

Kartini, D., \& Kristiawan, M. (2019). Pengaruh Tunjangan Profesi dan Motivasi Kerja Terhadap Kinerja Guru. Kelola: Jurnal Manajemen Pendidikan, 6(1), 25-33. https://doi.org/10.24246/j.jk.2019.v6.i1.p25-33.

Kristianti, L. S., Affandi, A., Nurjaya, N., Sunarsi, D., \& Rozi, A. (2021). Pengaruh Motivasi Dan Disiplin Kerja Terhadap Kinerja Pegawai Pada Dinas Pariwisata Purwakarta. Jurnal Ilmiah PERKUSI, 1(1), 101. https://doi.org/10.32493/j.perkusi.v1i1.9987.

Laksmi, N. L. P. sri, Agung, A. A. gede, \& Sudirman, S. (2019). Hubungan Kepemimpinan Pelayan, Kompetensi Manajerial Kepala Sekolah, Budaya Organisasi, dan Motivasi Kerja Dengan Kinerja Guru di Gugus PAUD Tunjung Kecamatan Denpasar Utara. 
Jurnal Administrasi Pendidikan Indonesia, 10(2), 148-156. https://doi.org/10.23887/japi.v10i2.2802.

Lutfiyanto, R. P., Huda, N., \& Hulmansyah, H. (2020). Pengaruh Pengembangan Karir dan Gaya Kepemimpinan Terhadap Kinerja Guru dengan Organizational Citizenhsip Behavior sebagai variabel mediasi (Study Pada Guru Sekolah Menengah Kejuruan). JEBA (Journal of Economics and Business Aseanomics), 5(2). https://doi.org/10.33476/j.e.b.a.v5i2.1658.

Manik, J., \& Siahaan, M. (2021). Pengaruh Keterampilan Manajerial Kepala Sekolah Dan Pemberian Reward Terhadap Kinerja Guru: Peran Motivasi Guru Sebagai Variabel Mediasi. Tadbir: Jurnal Manajemen Pendidikan Islam, 9(2), 145-163. https://doi.org/10.30603/tjmpi.v9i2.2267.

Messi, M., Anggita Sari, W., \& Murniyati, M. (2018). Pelaksanaan Supervisi Akademik Pengawas Sekolah Sebagai Upaya Peningkatan Profesionalisme Guru. JMKSP (Jurnal Manajemen, Kepemimpinan, Dan Supervisi Pendidikan), 3(1). https://doi.org/10.31851/jmksp.v3i1.1583.

Mukti, S. (2016). Pengaruh Tingkat Pendidikan dan Pengembangan Karir Terhadap Kinerja Karyawan. Jurnal Manajemen Indonesia, 4(1), 81-90. http://jurnal.uinbanten.ac.id/index.php/studiadidaktika/article/view/522.

Muspawi, M., Setiyadi, B., \& Gunawan, G. (2020). Upaya Kepala Sekolah Untuk Peningkatan Kompetensi Profesional Guru. Jurnal Ilmiah Universitas Batanghari Jambi, 20(1), 95. https://doi.org/10.33087/jiubj.v20i1.864.

Pala'langan, A. Y. (2020). Pengaruh servant leadership, disiplin kerja, dan kepuasan kerja terhadap kinerja guru. Jurnal Akuntabilitas Manajemen Pendidikan, 9(2), 223-231. https://doi.org/10.23887/jipp.v1i3.11983.

Prihartini, Y., Buska, W., Hasnah, N., \& Ds, M. R. (2019). Peran dan Tugas Guru dalam Melaksanakan 4 Fungsi Manajemen EMASLIM dalam Pembelajaran di Workshop. Islamika: Jurnal Ilmu-Ilmu Keislaman, 19(02), 79-88. https://doi.org/10.32939/islamika.v19i02.327.

Purwoko, S. (2018). Pengaruh kepemimpinan kepala sekolah, komitmen guru, disiplin kerja guru, dan budaya sekolah terhadap kinerja guru SMK. Jurnal Akuntabilitas Manajemen Pendidikan, 6(2), 150. https://doi.org/10.21831/amp.v6i2.8467.

Putri, A. D. K., \& Imaniyati, N. (2017). Pengembangan Profesi Guru Dalam Meningkatkan Kinerja Guru. Jurnal Pendidikan Manajemen Perkantoran, 2(2), 93. https://doi.org/10.17509/jpm.v2i2.8109.

Rochimah, H., Rugaiyah, R., \& Ahmad, M. (2018). Supervisi Kepala Sekolah Dan Konsep Diri Dalam Disiplin Kerja Guru PNS DI SMP Negeri. Jurnal Administrasi Pendidikan, 25(2), 234-251. https://doi.org/10.17509/jap.v25i2.18539.

Rusby, Z., \& Hamzah, Z. (2017). Pengaruh Pengembangan Karir dan Budaya Organisasi terhadap Kinerja Melalui Kepuasan Kerja Guru Sekolah Kebangsaan Kebun Sireh Pulau Pinang. Journal of Economic, Bussines and Accounting (COSTING), 1(1), 5667. https://doi.org/10.31539/costing.v1i1.47.

Saefullah, M. U., Haedari, A., \& Qolbi, L. (2019). Model Manajemen Sarana Dan Prasarana Dalam Pelayanan Pendidikan. Eduprof: Islamic Education Journal, 1(2), 1-12. https://doi.org/10.47453/eduprof.v1i2.19.

Sonedi, S., Sholihah, T., \& Dihasbi, D. (2018). Peran Kepemimpinan Kepala Sekolah dalam Meningkatkan Kinerja Guru. Anterior Jurnal, 18(1), 13-22. https://doi.org/10.33084/anterior.v18i1.436.

Suciningrum, F., Rhamanda, A. Z., \& Handayani, M. (2021). Pengaruh Motivasi Kerja Dan Disiplin Kerja Terhadap Kinerja Guru. SSRN Electronic Journal, 4(3), 2166-2172. https://doi.org/10.2139/ssrn.3864629. 
Sulfemi, W. B. (2020). Pengaruh Rasa Percaya Diri Dan Gaya Kepemimpinan Kepala Sekolah Terhadap Kinerja Guru. Nidhomul Haq : Jurnal Manajemen Pendidikan Islam, 5(2), 157-179. https://doi.org/10.31538/ndh.v5i2.557.

Sya'roni, Herlambang, T., \& Cahyono, D. (2018). Dampak Motivasi, Disiplin Kerja Dan Kepemimpinan Kepala Sekolah Terhadap Kinerja Guru. Jurnal Sains Manajemen Dan Bisnis Indonesia, 8(2). https://doi.org/10.32528/jsmbi.v8i2.1785.

Syaleh, H. (2018). Pengaruh Motivasi Dan Disiplin Kerja Terhadap Kinerja Guru Sekolah Menengah Atas Negeri 11 Sijunjung. Jurnal Ilmiah Ekonomi Dan Bisnis, 15(2), 150164. https://doi.org/10.31849/jieb.v15i2.1192.

Syamsul, H. (2017). Penerapan Kepemimpinan Kepala Sekolah Dalam Meningkatkan Kinerja Guru Pada Jenjang Sekolah Menengah Pertama (SMP). Idaarah: Jurnal Manajemen Pendidikan, 1(2). https://doi.org/10.24252/idaarah.v1i2.4271.

Tanjung, R., Hanafiah, H., Arifudin, O., \& Mulyadi, D. (2021). Kompetensi Manajerial Kepala Sekolah Dalam Meningkatkan Kinerja Guru Sekolah Dasar. JIIP - Jurnal Ilmiah Ilmu Pendidikan, 4(4), 291-296. https://doi.org/10.54371/jiip.v4i4.272.

Utari, K. T., \& Rasto, R. (2019). Pengaruh Disiplin Kerja Terhadap Kinerja Guru. Jurnal Pendidikan Manajemen Perkantoran, 238. https://doi.org/10.17509/jpm.v4i2.18019.

Wardhani, R. A. N., \& Wijaya, S. A. (2020). Pengaruh Kompetensi Terhadap Pengembangan Karir Dan Kinerja Guru Ekonomi SMA Negeri di Kota Jember. Jurnal Pendidikan Ekonomi Undiksha, 12(1), 148. https://doi.org/10.23887/jjpe.v12i1.24797.

Wijania, I. W. (2017). Kontribusi Kepemimpinan Pelayan Kepala Sekolah, Motivasi Kerja Dan Disiplin KerjaTerhadap Kinerja Guru. Jurnal Ilmiah Pendidikan Dan Pembelajaran, 1(4), 176-184. https://ejournal.undiksha.ac.id/index.php/JIPP/article/view/11983/7646.

Yuniati, S., \& Prayoga, S. (2019). Pengaruh Manajemen Perencanaan Pembelajaran Terhadap Kinerja Guru SMA Negeri di Kota Mataram. Jurnal Kependidikan: Jurnal Hasil Penelitian Dan Kajian Kepustakaan Di Bidang Pendidikan, Pengajaran Dan Pembelajaran, 5(2), 133. https://doi.org/10.33394/jk.v5i2.1811. 